\title{
Terrestrial and semi-aquatic scavengers on invasive Pacific pink salmon (Oncorhynchus gorbuscha) carcasses in a riparian ecosystem in northern Norway
}

\author{
Kathy M. Dunlop (D) Mark Wipfli · Rune Muladal • Grzegorz Wierzbinski
}

Received: 29 June 2020/Accepted: 6 November 2020/Published online: 7 December 2020

(C) The Author(s) 2020

\begin{abstract}
Pacific pink salmon (Oncorhynchus gorbuscha) invasions, thought to originate from populations introduced and established in Russia, occurred along the Norwegian coast in 2017 and 2019. Despite several thousand pink salmon entering and establishing in northern Norwegian rivers, current understanding of the ecological effect of the species in northern Europe is limited. Scavengers feeding on pacific salmon carcasses are important vectors for the transport of marine derived energy and nutrients to terrestrial ecosystems in the Pacific Northwest, North America, where the salmon naturally occur. However the role of terrestrial and aquatic scavengers in the consumption and removal of pink salmon beyond the salmon's native range is unknown. This study has identified terrestrial and sub-aquatic vertebrate scavengers on pink salmon carcasses in a sub-arctic river in northern Norway. Avian scavengers filmed by a camera placed near sites baited with pink salmon
\end{abstract}

K. M. Dunlop $(\bowtie)$

Institute of Marine Research, 9007 Troms $\varnothing$, Norway

e-mail: katherine.mary.dunlop@hi.no

M. Wipfli

U.S. Geological Survey, Alaska Cooperative Fish and Wildlife Research Unit, Institute of Arctic Biology, University of Alaska Fairbanks, Fairbanks,

AK 99775-7000, USA

R. Muladal · G. Wierzbinski

Naturtjenester i Nord, Holtveien 66, 9017 Troms $\varnothing$, Norway carcasses included the Eurasian magpie (Pica pica), hooded crow (Corvus cornix), common raven (Corvus corax), the European herring gull (Larus argentatus), redwing (Turdus iliacus) and goosander (Mergus merganser). However, the largest carcass weight was removed by red foxes (Vulpes vulpes). Carcasses entering Vesterelv River in 2019 were estimated to provide energy and nutrients to the river ecosystem an order of magnitude lower than in the Pacific Northwest. This study provides some of the first information in northern Europe on the mechanisms and quantification of energy and nutrient transfer from the ocean to riparian environments via introduced Pacific pink salmon. Results help to begin to determine the ecological effect of pink salmon and the development of appropriate management strategies.

Keywords Scavengers - Oncorhynchus gorbuscha . Sub-arctic riparian ecosystem · Introduced species

\section{Introduction}

Pacific salmon (genus; Oncorhynchus) are an ecological, economic and subsistence resource for countries of the North Pacific Rim (Schoen et al. 2017). Because of their attractiveness as a food and sport fish, they have been introduced far beyond their native geographical range (Groot and Margolis 1991). High 
cold-water tolerance and minimal use of the freshwater habitat has allowed Pacific pink salmon, herein referred to as pink salmon, populations to be successfully introduced and established in coastal northwest Russia. Pink salmon catches have been recorded in Norway since the 1960s, but in 2017 and 2019 major pink salmon invasions thought to originate from Russian populations and to be linked to favorable climatic conditions for pink salmon reproduction and survival, have occurred along the Norwegian coast. It is likely that several tens of thousands of adult spawners have entered the rivers (Mo et al. 2018; Sandlund et al. 2018). However, the ecological effect or role of pink salmon in Norwegian and European riverine ecosystems is currently relatively unknown (Jonsson and Jonsson 2018).

Pink salmon are an anadromous and semelparous species, that spend most of their lives feeding and maturing in the ocean, where they gain $95 \%$ of their mass before returning to rivers to spawn and die (Groot and Margolis 1991). The consumption of salmon carcasses by terrestrial and aquatic vertebrates in and alongside rivers is well known as a major pathway by which marine derived energy and nutrients (MDN) enter terrestrial and freshwater food webs (Ben-David et al. 1998; Cederholm et al. 1999; Wipfli et al. 2003). Salmon carcasses provide a valuable food source to terrestrial vertebrates (Reimchen 1994). As a result, linkages have been made between the occurrence of Pacific salmon runs and the diversity, abundance (Field and Reynolds 2013; Wilson and Halupka 1995), movement, feeding and reproductive patterns of vertebrates (Ben-David et al. 1997). Terrestrial vertebrates known to commonly scavenge on Pacific salmon carcasses in rivers in the Pacific Northwest of North America include bears (genus Ursus) (Quinn et al. 2009), wolves (Canis lupus), otter (Enhydra sp.), mink (Neovison vison), marten (Martes sp.) (Cederholm et al. 1989; Ben-David et al. 1997), eagles (Haliaeetus leucocephalus), vultures (Cathartes aura) and gulls (genus Larus) (Christie and Reimchen 2005; Shardlow and Hyatt 2013). In many of these studies, baited cameras have been used to identify and observe vertebrate scavengers and predators on Pacific salmon (Shardlow and Hyatt 2013; Levi et al. 2015). The method offers the ability to detect diurnal and nocturnal activities with reduced costs and human intervention.
The objective of this study was to identify terrestrial and sub-aquatic animal vectors that transport MDN via adult pink salmon carcasses in streams to riparian zones in a sub-arctic river system in northern Norway. An additional objective was to provide an initial quantification of the MDN transported by pink salmon carcasses to the river ecosystem and to the terrestrial environment by scavengers in northern Norway.

\section{Methods}

The study was conducted in the river Vesterelv, Eastern Finnmark, northern Norway. Vesterelv is over $19.6 \mathrm{~km}$ long and stretches from Lake Vesterelv to the bottom of the Varangerfjord and has an average width of $7 \mathrm{~m}$ (approximate area of $13,720 \mathrm{~m}^{2}$ ) and an annual mean flow of $2.5 \mathrm{~ms}^{-3}$ (Norwegian Watercourses and Energy Directorate 2017). Some of the largest numbers of pink salmon in Norway, entered and spawned in Vesterelv in 2017 (Sandlund et al. 2018).

Four motion-activated infrared stills imaging cameras (Browning Strike Force Pro XD with dual lens) were set on the riverbank to monitor wildlife scavenging activity on pink salmon carcasses. The cameras were set to capture five images rapidly when movement was detected. The long-range night exposure settings of the cameras allowed images of scavengers to be detected in all light levels. The identity and number of scavenger taxa was monitored before and during pink salmon spawning (16th July to 20th August 2019) to provide a relative comparison of wildlife activity prior to and after the introduction of pink salmon carcasses. Two unbaited cameras were placed on both side of the bank in the lower river reach $\left(70^{\circ} 7^{\prime} 12^{\prime \prime}, 28^{\circ} 29^{\prime} 56.4^{\prime \prime}\right)$ where pink salmon were spawning. Two further unbaited cameras were placed on both sides of the riverbank in a control location farther upstream where pink salmon were prevented from reaching by a waterfall $\left(70^{\circ} 6^{\prime} 57.6^{\prime \prime}, 28^{\circ} 31^{\prime}\right.$ $55.2^{\prime \prime}$ ). Cameras were placed approximately two meters from the riverbank and surveyed an area of approximately $4 \mathrm{~m}^{2}$. The monitoring of scavenging activities started on the 20th August 2019 and ended on the 5th September 2019 when all carcasses had been removed. The study was conducted during a period when the majority of pink salmon had completed spawning. The two cameras in the lower 
reaches were each baited with 25 pink salmon carcasses (10 females and 15 males), with a total weight of $\sim 30 \mathrm{~kg}$. Carcasses were spread evenly within the camera field of view on the riverbank. No carcasses were placed in front of the cameras in the upstream location to act as a control site. In addition, at the impacted site, a single time-lapse camera in an underwater housing was placed in the river at a depth of $\sim 0.5 \mathrm{~m}$ and baited with 10 pink salmon carcasses. The scavenging activity on underwater carcasses was monitored for $48 \mathrm{~h}$. Images from all four cameras were viewed in Adobe Photoshop CC 2019. Mammals or birds observed feeding on the carcasses were considered as scavengers, or scavengers of carcass-feeding insects, and were identified to species level. The maximum number of scavengers observed at the bait at one time $\left(\operatorname{Max}_{\mathrm{N}}\right)$, the time between the placement of the carcasses and the arrival of the first scavenger $\left(\mathrm{t}_{\text {arrival }}\right)$ and the time taken to reach $\operatorname{Max}_{\mathrm{N}}\left(\mathrm{t}_{\operatorname{maxN}}\right)$ are all recognized proxies of scavenger abundance (Langlois et al. 2018). These parameters were calculated for each camera set of images before and after the time of carcass placement.

The energy transported to the river by pink salmon carcasses was calculated by multiplying the energy ( $\left.3.31 \mathrm{KJ} \mathrm{g}^{-1}\right)$ and the nitrogen $(2.4 \%$ carcass weight) and phosphorous percentage content $(0.4 \%$ carcass weight) averaged for chum and pink salmon carcasses from Gende et al. (2003) by the estimated biomass of pink salmon in Vesterlev. Biomass was estimated from the recorded weights of male and female carcasses $(n=10)$ and the estimated number of pink salmon that entered the river in 2019. The number of pink salmon entering Vesterelv during the study period was estimated from anadromous fish counts recorded in 2017 and 2019 (Berntsen et al. 2020; R. Muladal, unpublished data). Counts were conducted by snorkeling studies in 2017 that followed the Norwegian standard for the "visual registration of anadromous salmonids in watercourses" and local catches of pink salmon recorded in 2017 and 2019. The energy and nutrient budgets in the carcasses were quantified over the river area $\left(13,720 \mathrm{~m}^{2}\right)$. The rate of removal of the carcasses $\left(\mathrm{kg} \mathrm{day}^{-1}\right)$ was calculated by dividing the weight of the carcasses $(30 \mathrm{~kg})$ by the days elapsed before the carcasses were completely removed. The percentage of carcasses removed each day was used to calculate the rate of MDN transfer to
the
$\left(\mathrm{KJ}_{\text {day }}{ }^{-1} \mathrm{~m}^{-2}\right.$ ).
terrestrial
environment

\section{Results}

Five bird species, that included the Eurasian magpie (Pica pica), hooded crow (Corvus cornix), common raven (Corvus corax), the European herring gull (Larus argentatus) and the redwing (Turdus iliacus), attended and fed on the pink salmon carcasses (Fig. 1). Redwing were however, most likely to be feeding on the adult or larval insects on the carcasses. Magpies were the first scavenger species to arrive at the bait at camera one with a $\mathrm{t}_{\text {arrival }}$ of $15 \mathrm{~h} 2 \mathrm{~min}$. At camera two, the first arrival was a European red fox (Vulpes vulpes) at $2 \mathrm{~h} 12$ min after the bait was placed in front of the cameras. Ravens were the most common scavenger at both carcass sites and reached $\mathrm{a} \mathrm{Max}_{\mathrm{N}}$ of five individuals at a $\operatorname{tmax}_{\mathrm{N}}$ of $43 \mathrm{~h}$ and at $57 \mathrm{~h}$. Magpies and hooded crows generally attended the bait in pairs $\left(\operatorname{Max}_{N}=2\right)$. All three of these bird species fed during daylight hours whereas it was common to see an individual redwing and/or herring gull continue to feed on the bait some hours after sunset or early in the morning (Fig. 2). The red fox was the only mammal observed to scavenge on the pink salmon carcasses. Several foxes, that could be identified as different individuals by their coat markings, visited the carcasses during the day and night and removed whole carcasses into the riparian vegetation. At both carcass sites the maximum number of scavengers observed at the bait at one time was 5 .

A goosander (Mergus merganser) was captured feeding on the pink salmon carcasses in the river (Fig. 1). In the period before and during spawning when cameras were unbaited, an individual redwing and two common mergansers were observed passing the camera at the soon-to-be carcass site. At the control site a red fox, a hooded crow and a Eurasian otter (Lutra lutra) passed the camera, pre-treatment. In the control site after spawning, a single common merganser passed the camera.

In Vesterelv in $2017,>1500$ pink salmon were caught and $>600$ were observed in snorkeling studies. In 2019, the local catch was 1681 pink salmon leading to an estimated of, 2000-2500 pink salmon entered the river annually in both 2017 and 2019. This makes the spawning population of pink salmon five times larger 


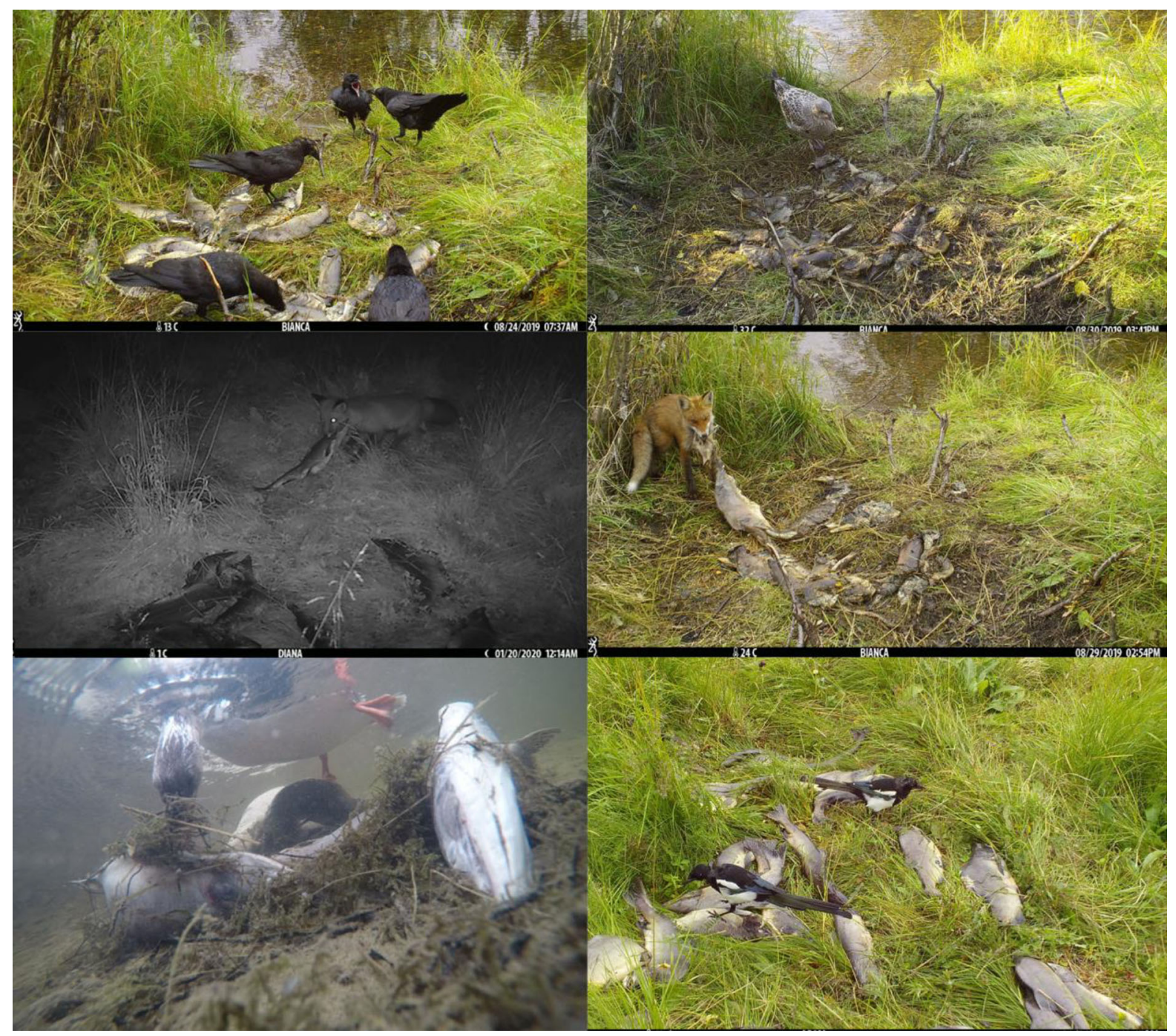

Fig. 1 Images of terrestrial and sub-aquatic scavenging fauna feeding on pink salmon (Oncorhynchus gorbuscha) carcasses in Vesterelva, Finnmark

than that of the native mature anadromous resident salmonid populations of Atlantic salmon (Salmo salar) and brown trout (Salmo trutta) (Muladal, pers.obs.). Therefore, the biomass of carcasses entering Vesterelv in 2019 was estimated between 2.2 and 2.7 tons, which provides between 533.4 and $666.7 \mathrm{~kJ}^{\text {energy } \mathrm{m}^{-2}}$ to river biota. In addition, carcasses can provide between 3.9 and $4.8 \mathrm{~g} \mathrm{~m}^{-2}$ nitrogen and $0.7-0.8 \mathrm{~g} \mathrm{~m}^{-2}$ phosphorus to the river ecosystem. During the study period terrestrial birds and mammals removed $5.9 \%$ of the carcass biomass each day. If this rate of removal is extrapolated to the whole biomass of carcasses entering the river then each day terrestrial megafauna can transfer between 32 and $40 \mathrm{~kJ}$ of energy $\mathrm{m}^{2}, 0.23-0.29 \mathrm{~g} \mathrm{~m}^{-2}$ nitrogen and $0.04-0.05 \mathrm{~g} \mathrm{~m}^{-2}$ phosphorus to the riparian environment surrounding Vesterelv.

\section{Discussion}

This study showed that invasive adult Pacific pink salmon carcasses can serve as a food source for terrestrial and sub-aquatic avian and mammalian wildlife in northern Norway. Birds and foxes were a dispersal pathway for the transport of marine-derived 


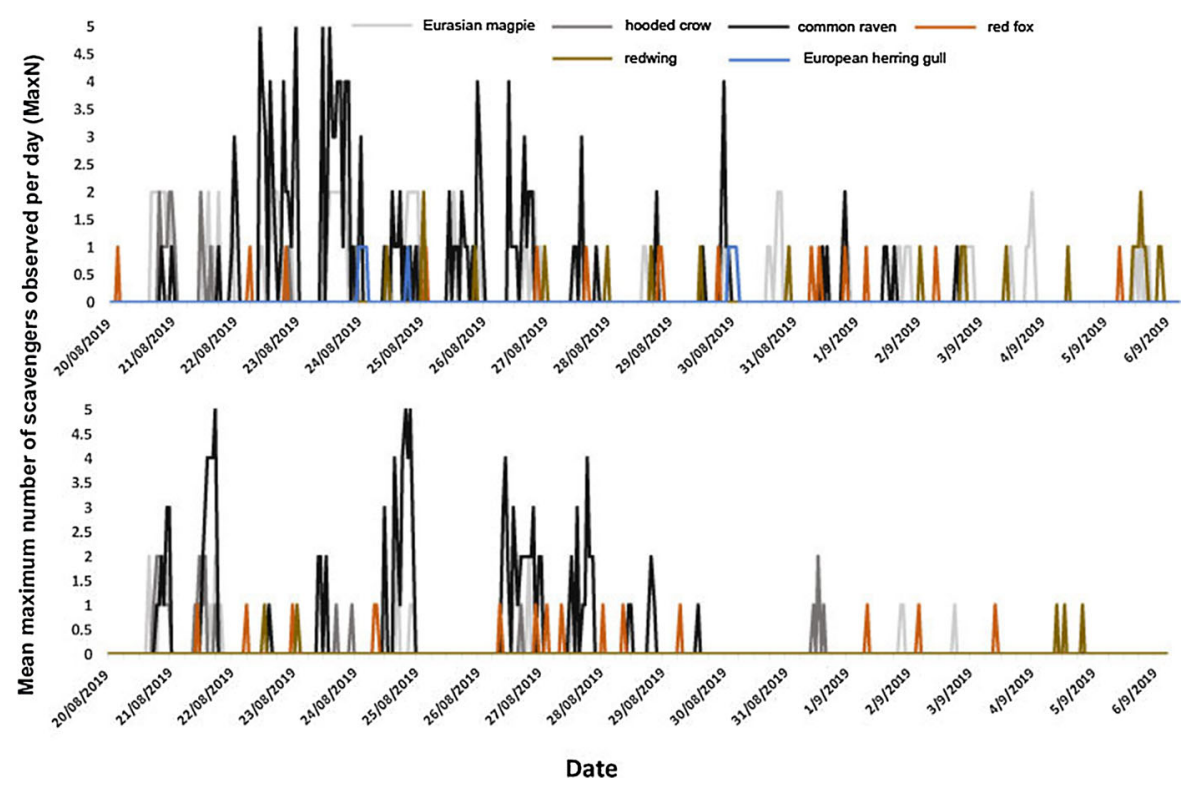

Fig. 2 Mean maximum number of scavenger species observed per day feeding on pink salmon (Oncorhynchus gorbuscha) carcasses in Vesterelva, Finnmark. Each graph represents the scavengers observed in a single camera

nutrients (carbon, nitrogen and phosphorous) and energy from pink salmon carcasses to the terrestrial ecosystem as is commonly observed in northwest USA and Canada where pink salmon occur naturally (Gende et al. 2003). The foxes at river Vesterelv were presumed to cache carcasses and thus in combination with the droppings of other scavengers, transfer marine-derived nutrients and energy into the riparian environment. Once these nutrients and energy enter the riparian ecosystem they can result in an increase in terrestrial invertebrates and vertebrates that feed on salmon biomass (Field and Reynolds 2013) and increased growth of terrestrial vegetation (Ben-David et al. 1998; Bilby et al. 2003). The bird fauna scavenging on the pink salmon carcasses in Vesterelv included species that are known salmon scavengers in the Pacific Northwest (Christie and Reimchen 2005). The goosander feeds on live salmonids in northern Norway (Kålås et al. 1993) but this work observed them feeding as scavengers which has previously been unrecorded. It is possible that the ten carcasses in the river were removed by goosanders. Red foxes also scavenge on salmon carcasses in Alaska (Gard 1971). Other terrestrial and sub-aquatic wildlife common in northern Norway that were not observed as scavengers in this study but are still likely to scavenge on pink salmon carcasses include the Eurasian otter (Lutra lutra) and white-tailed eagle (Haliaeetus albicilla).

The MDN transferred by pink salmon carcasses to Vesterelv and into the terrestrial environment by scavengers is an order of magnitude lower than often recorded in their natural environments, although that ranges widely depends upon the nature of the streams, size of the salmon runs, and densities of vertebrate scavengers and predators (M. Wipfli, pers. obs.). For example, Gende et al. (2003) estimated that $5455 \mathrm{~kJ} \mathrm{~m}^{-2}$ energy, $37 \mathrm{~g}$ of nitrogen, $5.3 \mathrm{~g}$ of phosphrous was transported to each $\mathrm{m}^{2}$ of stream area in Bear Creek, southeastern Alaska, via chum and pink salmon adults, where these salmon species, and vertebrate predators and scavengers, are abundant. This does not take into account the MDN provided by energy rich pink salmon eggs. However, the energy transferred to Vesterelv by pink salmon is significantly greater than the energy and nutrients supplied to the River Imsa in Norway by the carcasses of the native Atlantic salmon $\left(38 \times 10^{3} \mathrm{~kJ}\right.$ energy per year $)$ and 117 and $23 \mathrm{~kg}$ of nitrogen and phosphorous per year (Jonsson and Jonsson 2002). Therefore, the MDN from current pink salmon runs in northern Norway will not impact riverine and aquatic ecosystems to the same extent they do in northeast Pacific. However, pink salmon carcasses do represent a new and larger 
source of MDN than native salmonids and has the potential to influence the structure and distribution of local wildlife communities.

Pink salmon carcasses have the potential to become an important seasonal food resource in rivers to these scavenger species where large numbers of pink salmon continue to return. The consumption of pink salmon carcasses could have an adaptive value to terrestrial and sub-aquatic fauna in northern Norway, as has been predicted for terrestrial wildlife predating on salmon in Alaska (Ben-David et al. 1997; Darimont et al. 2008). If the input of this new resource continues it will have the potential to impact local ecological processes such as competition and predation (Gende and Quinn 2004). For example, carcasses can serve to enhance the survival of scavenging fauna and as a result increase population numbers, which in turn can impact the populations of prey or competitors.

In summary, this study provides some of the first information in northern Europe on the mechanisms and quantification of energy and nutrient transfer from the ocean to riparian environments via Pacific pink salmon. Further studies should identify which species benefit, which do not, and which might suffer negative consequences from invasive pink salmon in Norway. We can anticipate there will be both 'winners' and 'losers' from adult pink salmon runs in the future, in both terrestrial and freshwater ecosystems.

Acknowledgements We would like to acknowledge funding from the Fram Centre Terrestrial Flagship and project management and administration by Guttorm Christensen (Akvaplan-niva) and local assistance of the river Vesterelv guard Ottar Store. We are also grateful for the reviews provided by Neil Metcalf, University of Glasgow, and two anonymous reviewers whose comments helped improve the manuscript. Any use of trade, firm, or product names is for descriptive purposes only and does not imply endorsement by the U.S. Government.

Authors contribution K. Dunlop, M. Wipfli, R. Muladal and G. Wierzbinski were involved in the design of the study and the collection of data in the field. K. Dunlop analysed the data and lead the writing of the first draft of the manuscript. All other author (M. Wipfli, R. Muladal and G. Wierzbinski) contributed to subsequent drafts. The final draft was read and approved by all authors.

Funding Open Access funding provided by Institute Of Marine Research. Funding was received by the Fram Centre Terrestrial Flagship in 2019.
Data availability Data has been made available on Mendeley Data and are also available from the corresponding author on reasonable request.

\section{Compliance with ethical standards}

Conflict of interest The authors declare that they have no conflict of interest.

Open Access This article is licensed under a Creative Commons Attribution 4.0 International License, which permits use, sharing, adaptation, distribution and reproduction in any medium or format, as long as you give appropriate credit to the original author(s) and the source, provide a link to the Creative Commons licence, and indicate if changes were made. The images or other third party material in this article are included in the article's Creative Commons licence, unless indicated otherwise in a credit line to the material. If material is not included in the article's Creative Commons licence and your intended use is not permitted by statutory regulation or exceeds the permitted use, you will need to obtain permission directly from the copyright holder. To view a copy of this licence, visit http://creativecommons.org/licenses/by/4.0/.

\section{References}

Ben-David M, Hanley TA, Klein DR, Schell DM (1997) Seasonal changes in diets of coastal and riverine mink: the role of spawning Pacific salmon. Can J Zool 75:803-811. https://doi.org/10.1139/z97-102

Ben-David M, Hanley TA, Schell DM (1998) Fertilization of terrestrial vegetation by spawning Pacific salmon: the role of flooding and predator activity. OIKOS 83:47-55. https:// doi.org/10.2307/3546545

Berntsen HH, Sandlund OT, Thorstad EB, Fiske P (2020) Pukkellaks i Norge, 2019. NINA Rapport 1821. Norwegian Institute for Nature Research. https://hdl.handle.net/11250/ 2651741

Bilby RE, Beach EW, Fransen BR, Walter JK, Bisson PA (2003) Transfer of nutrients from spawning salmon to riparian vegetation in western Washington. Trans Am Fish Soc 132:733-745. https://doi.org/10.1577/T02-089

Cederholm CJ, Houston DB, Cole DL, Scarlett WJ (1989) Fate of coho salmon (Oncorhynchus kisutch) carcasses in spawning streams. Can J Fish Aquat Sci 46:1347-1355. https://doi.org/10.1139/f89-173

Cederholm CJ, Kunze MD, Murota T, Sibatani A (1999) Pacific salmon carcasses: essential contributions of nutrients and energy for aquatic and terrestrial ecosystems. Fisheries 24:6-15. https://doi.org/10.1577/15488446(1999)024<0006:PSC > 2.0.CO;2

Christie KS, Reimchen TE (2005) Post-reproductive Pacific salmon, Oncorhynchus spp., as a major nutrient source for large aggregations of gulls, Larus spp. Can Field Nat 119:202-207. https://doi.org/10.22621/cfn.v119i2.107

Darimont CT, Paquet PC, Reimchen TE (2008) Spawning salmon disrupt trophic coupling between wolves and ungulate prey in coastal British Columbia. BMC Ecol 8. https://doi. org/10.1186/1472-6785-8-14 
Field RD, Reynolds JD (2013) Ecological links between salmon, large carnivore predation, and scavenging birds. J Avian Biol 44:9-16. https://doi.org/10.1111/j.1600-048X.2012. 05601.x

Gard R (1971) Brown bear predation on sockeye salmon at Karluk Lake, Alaska. J Wildl Manag 35:193-204. https:// doi.org/10.2307/3799591

Gende SM, Quinn TP (2004) The relative importance of prey density and social dominance in determining energy intake by bears feeding on Pacific salmon. Can J Zool 82:75-85. https://doi.org/10.1139/z03-226

Gende SM, Quinn TP, Wilson MF, Heintz R, Scott TM (2003) Magnitude and fate of salmon-derived nutrients and energy in a coastal stream ecosystem. J Freshw Ecol 19:149-160. https://doi.org/10.1080/02705060.2004.9664522

Groot C, Margolis L (1991) Pacific salmon life histories. University of British Columbia Press

Jonsson B, Jonsson N (2002) Migratory Atlantic salmon as vectors for the transfer of energy and nutrients between freshwater and marine environments. Freshw Biol 48:21-27. https://doi.org/10.1046/j.1365-2427.2003. 00964.x

Jonsson N, Jonsson B (2018) Comment on "The pink salmon invasion: a Norwegian perspective" (Mo et al., 2018). Freshw Biol 48:21-27. https://doi.org/10.1111/jfb.13814

Kålås JA, Heggberget TG, Bjørn PA, Reitan O (1993) Feeding behaviour and diet of goosanders (Mergus merganser) in relation to salmonid seaward migration. Aquat Living Resour 6:31-38. https://doi.org/10.1051/alr:1993003

Langlois T et al (2018) Marine sampling field manual for benthic stereo BRUVS (Baited Remote Underwater Videos). In: Przeslawski R, Foster S (eds) Field manuals for marine sampling to monitor Australian waters. National Environmental Science Programme (NESP). pp 82-104

Levi T, Wheat RE, Allen JM, Wilmers CC (2015) Differential use of salmon by vertebrate consumers: implications for conservation. PeerJ 3:e1157. https://doi.org/10.7717/peerj. 1157

Mo TA, Thorstad EB, Sandlund OT, Berntsen HH, Fiske P, Uglem I (2018) The pink salmon invasion: a Norwegian perspective. J Fish Biol 93:5-7. https://doi.org/10.1111/jfb. 13682

Norwegian Watercourses and Energy Directorate (2017) 241/4 Vesterelva til Meskfjorden. https://www.nve.no/vannvassdrag-og-miljo/verneplan-for-vassdrag/finnmark/241-

4-vesterelva-til-meskfjorden-njidggujohka/

Quinn TP, Carlson SM, Gende SM, Rich HB (2009) Transportation of Pacific salmon carcasses from streams to riparian forests by bears. Can J Zool 87:195-203. https:// doi.org/10.1139/Z09-004

Reimchen TE (1994) Further studies of predator and scavenger use of chum salmon in stream and estuarine habitats at bag harbour, Gwaii Haanas. Islands Ecological Research, Queen Charlotte City

Sandlund OT et al (2018) Pink salmon in Norway: the reluctant invader. Biol Invasions 21:1033-1054. https://doi.org/10. 1007/s10530-018-1904-z

Schoen ER et al (2017) Future of Pacific salmon in the face of environmental change: lessons from one of the world's remaining productive salmon regions. Fisheries 42:538-553. https://doi.org/10.1080/03632415.2017. 1374251

Shardlow TF, Hyatt KD (2013) Quantifying associations of large vertebrates with salmon in riparian areas of British Columbia streams by means of camera-traps, bait stations, and hair samples. Ecol Indic 27:97-107. https://doi.org/10. 1016/j.ecolind.2012.11.011

Wilson MF, Halupka KC (1995) Anadromous fish as keystone species in vertebrate communities. Conserv Biol 9:489-497. https://doi.org/10.1046/j.1523-1739.1995. 09030489.x

Wipfli MS, Hudson JP, Caouette JP, Chaloner DT (2003) Marine subsidies in freshwater ecosystems: salmon carcasses increase the growth rates of stream-resident salmonids. Trans Am Fish Soc 132:371-381. https://doi.org/ 10.1577/1548-8659(2003)132<0371:MSIFES >2.0.CO;2

Publisher's Note Springer Nature remains neutral with regard to jurisdictional claims in published maps and institutional affiliations. 